\title{
Announcement
}

\section{5th World Stroke Congress}

Vancouver, B.C., Canada, J une 23-26, 2004

For further information, please contact:

5th World Stroke Congress

Kenes International - Global Congress Organisers and Association Management Services

17 Rue du Cendrier, PO Box 1726

CH-1211 Geneva 1 (Switzerland)

Tel. +4122908 0488, Fax +41227322850

E-Mail stroke2004@kenes.com 